\title{
Investigating Acid Stress Response in Different Saccharomyces Strains
}

\author{
Rogelio Lopes Brandão, ${ }^{1}$ Júlio César Câmara Rosa, ${ }^{1}$ \\ Jacques Robert Nicoli, ${ }^{2}$ Marcos Vinicius Simi Almeida, ${ }^{1}$ Ana Paula do Carmo, ${ }^{1}$ \\ Heloa Teixeira Queiros, ${ }^{1}$ and Ieso Miranda Castro ${ }^{1,3}$ \\ ${ }^{1}$ Núcleo de Pesquisas em Ciências Biológicas, Escola de Farmácia, Universidade Federal de Ouro Preto, \\ Campus Morro do Cruzeiro, 35400-000 Ouro Preto, MG, Brazil \\ ${ }^{2}$ Departamento de Microbiologia, Instituto de Ciências Biológicas, Universidade Federal de Minas Gerais, \\ Campus Universitário, 30171-970 Belo Horizonte, MG, Brazil \\ ${ }^{3}$ LBCM, Instituto de Ciências Exatas e Biológicas, Campus Morro do Cruzeiro, 35400-000 Ouro Preto, MG, Brazil
}

Correspondence should be addressed to Ieso Miranda Castro; imcastro@nupeb.ufop.br

Received 3 February 2014; Accepted 1 April 2014; Published 17 April 2014

Academic Editor: Praveen Rao Juvvadi

Copyright (C) 2014 Rogelio Lopes Brandão et al. This is an open access article distributed under the Creative Commons Attribution License, which permits unrestricted use, distribution, and reproduction in any medium, provided the original work is properly cited.

Yeast cells need to respond to a variety of stresses found in such different conditions as gastrointestinal tract after probiotic ingestion or fermentation vat during ethanol production. In the present study, $\mathrm{H}^{+}$neutralisation capacity, membrane fatty acid composition, $\mathrm{H}^{+}$-ATPase activity, and cytosolic $\mathrm{Ca}^{2+}$ concentration were evaluated in yeast cells used for probiotic (Saccharomyces boulardii) and laboratory (Saccharomyces cerevisiae W303) purposes, as well as in some W303 mutant strains for ENA1 gene and S. cerevisiae BY4741. Results show that the $\mathrm{H}^{+}$internal concentration of yeast is regulated by several systems, including the plasma membrane $\mathrm{H}^{+}$-ATPase, and that Enalp has an important but undefined role in the cellular response to acid. Membrane fatty acid composition of $S$. cerevisiae W303 strain was affected by exposure to acidic $\mathrm{pH}$, but the presence of $86 \mathrm{mM} \mathrm{NaCl}$ prevented this effect, whereas membrane fatty acid composition of $S$. boulardii was unaffected by acidic $\mathrm{pH}$. We also demonstrated that the acid stress response is dependent on calcium metabolism and blocked by FK 506 .

\section{Introduction}

To survive and proliferate, free-living organisms must adapt to changes in their environment. Exposure of the Saccharomyces cerevisiae to environmental stresses, such as toxic ions [1,2], ethanol [3], or changes in temperature [4] or $\mathrm{pH}[5]$, triggers biochemical and gene expression changes [6]. Yeast rapid exposure to inorganic acids is of interest, because such exposure occurs under environmental (e.g., yeast probiotics passing through the gastrointestinal system) and industrial conditions (e.g., sulphuric acid to eliminate bacterial contamination in yeast cultures that are to be reused for fermentation [7]).

Saccharomyces cerevisiae grows well over a wide range of $\mathrm{pH}$ but grows better in acidic than in alkaline $\mathrm{pH}[5$, 8]. Studies have demonstrated changes in the expression of hundred genes in S. cerevisiae following alterations in $\mathrm{pH}$ [9-11]. The responses of $S$. cerevisiae to alkaline $\mathrm{pH}$ have been reviewed by Ariño [5] and involve various signalling pathways. In particular, the role of calcineurin on alkaline stress was suggested early on, and the involvement of calcium signalling in this response was reported in subsequent works $[5,10,12,13]$. Responses to alkaline $\mathrm{pH}$ have also been described for Candida albicans [14] and Aspergillus nidulans $[15,16]$.

Responses to acid stress have been studied in yeast cells that were artificially exposed to weak organic acids $[9,17]$, food preservatives [17, 18], and herbicides [19]. In response to exposure to weak acids, yeast cells show decreased membrane permeability, anion extrusion, an increased ability to catabolize preservatives [20], and altered gene expression [9]. Results of genomewide analysis and functional screening of 
TABLE 1: Saccharomyces cerevisiae strains used in this study.

\begin{tabular}{|c|c|c|}
\hline Strain & Genotype & Source \\
\hline S. boulardii & Wild type & FLORATIL, Merck S.A. \\
\hline W303 & $\begin{array}{l}\text { Mat } \alpha \text { leu2-3, } 112 \text { ura3-1 trp1-1 his3-11 } \\
15 \text { ade2-1 can1-100 GAL mal SUC2 }\end{array}$ & Johan M. Thevelein \\
\hline LBCM 479 & W303 Mat $\alpha$ ena1::HIS3::ena4 & José Ramos \\
\hline LBCM 690 & LBCM479 [p417] & This work \\
\hline LBCM 691 & LBCM479 [p427] & This work \\
\hline LBCM 692 & LBCM479 [p417::ENA1] & This work \\
\hline LBCM 693 & LBCM479 [p427::ENA1] & This work \\
\hline BY4741 & MATa his $3 \Delta 1$ leu $2 \Delta 0 \operatorname{lis} 2 \Delta 0 \operatorname{ura} 3 \Delta 0$ & Euroscarf \\
\hline YKL190W & BY4741 cnb1::KanMX4 & Euroscarf \\
\hline YNL027W & BY4741 crz1::KanMX4 & Euroscarf \\
\hline
\end{tabular}

genes involved in response to lactic, acetic, and hydrochloric acids suggest that acidic conditions affect cell wall architecture, the expression of genes involved in metal metabolism, vacuolar $\mathrm{H}^{+}$-ATPase (V-ATPase), and HOG MAPK protein levels [17].

Similar to the response to weak acids, resistance to inorganic acid exposure involves changes in the membrane conductivity to $\mathrm{H}^{+}$, active extrusion of protons from the cell [21], and the modulation of gene expression $[8,17]$. Previous studies have shown that the protein kinase $\mathrm{C}$ (PKC) pathway involved in cell integrity in S. cerevisiae is activated in response to acid stress and that this activation is dependent on the cell wall sensor Mid2p [22-24]. Claret et al. have suggested the existence of two distinct pathways, involving Mid2p (cell wall sensor) or Rgd1p (Hog pathway) that act together to induce cell integrity pathway and to increase acidic tolerance [22].

In Saccharomyces, cytosolic calcium plays an essential role in the control of the cell cycle, budding process, and mating. Additionally, cytosolic calcium is an important second messenger in eukaryotic cells. Yeast cells growing under standard laboratory conditions exhibit low cytosolic calcium levels and minimal calcineurin activity [25]. Exposure to various environmental stresses, such as salt, oxidative, alkali, or heat stress, causes immediate changes in the cytosolic calcium. Calcium levels first increase and then decline rapidly when yeast cells are exposed to these conditions [10, 14, 26-28]. Crz1 is the major effector of calcineurin-regulated gene expression in $S$. cerevisiae, but unidentified targets for calcineurin with roles in stress adaptation also exist [5]. The Cch1 and Mid1 proteins, components of membrane calcium channel, and effectors of Slt2p (PKC pathway) are involved in cell viability at low $\mathrm{pH}$ in Saccharomyces [22]. However, calcium-mediated signalling mechanisms have not been studied under the acidshock response.

In a previous work carried out in our laboratory, we established that low concentrations of sodium ions conferred protection to yeast cells exposed to acid stress [29]. Our observations also suggested that the systems involved in maintaining the plasma membrane potential (PMAlp $\mathrm{H}^{+}$ATPase and secondary transporter systems) were linked to the acid stress response. In the present study, we focused experiments on plasma membrane $\mathrm{H}^{+}$-ATPase participation and on calcium signalling events observed in yeast cells in response to acid stress.

\section{Materials and Methods}

2.1. Yeast Strains and Growth Conditions. Table 1 lists the yeast strains used in this study. Yeast strains were grown in an orbital shaker $(200 \mathrm{rpm})$ at $30^{\circ} \mathrm{C}$ in YPD medium containing $(\mathrm{w} / \mathrm{v}) 1 \%$ yeast extract, $2 \%$ peptone, and $2 \%$ glucose. Cellular growth was monitored by optical density (OD) at $600 \mathrm{~nm}$.

2.2. Acid Stress Condition and Viability Assays. Yeast cell cultures $\left(\mathrm{OD}_{600 \mathrm{~nm}} \sim 1.0\right)$ were harvested by centrifugation at $4,750 \times \mathrm{g}$ for $5 \mathrm{~min}$ and washed twice with YP media. Then pellets were suspended at an OD600 $\mathrm{nm}$ of $1.0 \mathrm{in}$ an aqueous solution, previously adjusted to $\mathrm{pH} 2.0$ with $1 \mathrm{M}$ $\mathrm{HCl}$ and supplemented with $86 \mathrm{mM} \mathrm{NaCl}$. This condition was applied to every acid treatment performed in this study. Yeast samples were then incubated in an orbital shaker at $30^{\circ} \mathrm{C}$ for $1 \mathrm{~h}$. Aliquots were collected after 0 (control cells, before acid stress), 15, 30, and $60 \mathrm{~min}$ of incubation. Cells were immediately washed twice with an equal volume of YP and diluted $20,000 \times$. Then, $50 \mu \mathrm{L}$ of cell suspension was seeded on YPD agar. Plates were incubated at $30^{\circ} \mathrm{C}$ for 48 to $72 \mathrm{~h}$. The results were expressed as the percentage (\%) of colony forming units ( $\mathrm{cfu}$ ) relative to the control sample $(t=0)$.

The growth of yeast cells in the presence of $\mathrm{Na}^{+}$was tested on a series of YPD plates supplemented with increasing concentrations of $\mathrm{NaCl}(200-500 \mathrm{mM})$. Tenfold serial dilutions of cell suspensions were prepared, and $5 \mu \mathrm{L}$ aliquots of each were spotted onto YP plates. Growth was monitored over 3 days.

2.3. $\mathrm{H}^{+}$Neutralisation Capacity of the Yeast Cells. The capacity of cells to neutralise added $\mathrm{H}^{+}$to a cell suspension was determined by an acid-pulse technique with a $\mathrm{pH}$ meter. Briefly, the $\mathrm{pH}$ was measured after the addition of acid pulses [30]. To estimate the extracellular capacity to neutralise added $\mathrm{H}^{+}$, the cells were grown as previously described, washed, and either exposed (stressed cells) or not (control 
cells) to acid stress. Aliquots of $50 \mathrm{~mL}$ were collected by centrifugation, washed twice with Milli-Q water, and resuspended in a $2 \mathrm{~mL}$ volume to obtain a dense cell suspension. The $\mathrm{pH}$ of cell suspension was previously adjusted in $\mathrm{pH} 6.8$ with $\mathrm{NaOH}$ and the first acid pulses were performed with small volumes of $10 \mathrm{mM} \mathrm{HCl}$, because near the neutral $\mathrm{pH}$ range even the addition of small amounts of protons results in large $\mathrm{pH}$ changes. To estimate the total cell capacity to neutralise $\mathrm{H}^{+}$(meaning the ability of cell surface-derived chemical groups plus internal metabolites), the cells were previously disrupted with liquid nitrogen in Milli-Q water and resuspended as described before.

2.4. Determination of $H^{+}$-ATPase Activity. Measurements of $\mathrm{H}^{+}$-ATPase activity were made with $375 \mathrm{mg}$ of cells (wet weight) grown in YPD (4\% glucose) to an $\mathrm{OD}_{600}$ of $1.0-$ 1.2 (control) or cells grown in YPD, washed, exposed to acid stress, as described above, and harvested after 10, 30, and $60 \mathrm{~min}$. After recover on glass fiber filters, the cells were removed from the filters, immediately frozen in liquid nitrogen, and stored until use. Plasma membrane isolation and determination of ATPase activity, in the presence of inhibitors of mitochondrial ATPase and phosphatase, were performed as previously described [31]. Protein content was determined by the Lowry method [32].

2.5. Intracellular Free Calcium Concentration. The cytosolic free calcium concentration was measured by the aequorinbased method [33] with some modifications. The pVTUAEQ plasmid was a gift from Marco Vanoni (Università di Milano-Bicocca, Milan, Italy). Briefly, exponentially growing cells transformed with the multicopy apoaequorinexpressing plasmid pVTU-AEQ were harvested by centrifugation at $4,750 \times \mathrm{g}$ for $5 \mathrm{~min}$, washed three times with Mes/Tris $0.1 \mathrm{M}$ ( $\mathrm{pH}$ 6.5), and resuspended at a density of $\sim 10^{9}$ cells $/ \mathrm{mL}$. To reconstitute functional aequorin, $50 \mu \mathrm{M}$ coelenterazine (Molecular Probes; stock solution $1 \mu \mathrm{g} / \mu \mathrm{L}$ dissolved in methanol) was added to the cell suspension, and the cells were incubated for $30 \mathrm{~min}$ at room temperature in the dark. Excess coelenterazine was removed by washing the cells three times with Milli-Q water and centrifuging at $3,200 \times \mathrm{g}$ for $3 \mathrm{~min}$.

For each acid pulse (pH 2.0 plus $86 \mathrm{mM} \mathrm{NaCl}$ ), $450 \mu \mathrm{L}$ of cell suspension (in water) was transferred to a luminometer tube. Light emission was monitored in a Berthold Lumat LB 9501/16 luminometer at $2 \mathrm{~s}$ intervals starting $1 \mathrm{~min}$ before and lasting until $>6 \mathrm{~min}$ after $\mathrm{HCl}$ addition to the final concentration indicated in the figures. The results summarise three replicates and are expressed in relative luminescence units per second (RLU/s).

2.6. Analysis of Membrane Fatty Acid Composition. The Microbial Identification System (MIS, Microbial ID Inc., Newark, DE, USA) was used to analyse the fatty acid composition of cytoplasmic membranes [34]. Methyl esters were obtained according to the MIDI method (Microbial ID Inc.). Methyl esters were identified and quantified by chromatography with the Sherlock software package (MIDI Inc., version
4.5). Arcsine square root transformations were performed. Data were analysed by analysis of variance (ANOVA) with the Scott Knott test at 5\% significance. Transformations and analyses were performed with the Genes software package, version 2007.0.0, which allows for the study of microbial genetic diversity from membrane fatty acid composition [35]. Data were analysed by the standardized Euclidian distance, and the calculated matrix distance was used for clustering analysis by the UPGMA method (Unweighted Pair Group Method with Arithmetic Mean).

2.7. Molecular Biological Methods. Preparation and manipulation of nucleic acids (e.g., phenol extraction, ethanol precipitation, and electrophoresis) were performed as described by Sambrook et al. [36].

The plasmids p417-CYC (low copy) and p427-TEF (high copy), purchased from Dualsystems Biotech AG, Switzerland, were used to express ENA1 (YDR040C, Saccharomyces cerevisiae Genome Database, http://www.yeastgenome.org/). The insert was prepared by using yeast genomic DNA from the W303 strain as a template. The primers were forward, GACTAGTATG GGCGAAGGAACTACTAAG; and reverse, TCCCCCGGGTCATTGTTTAT ACCAATATTAAC. The forward PCR primer contained a Spel site, and the reverse primer had a Smal site. The PCR product was cut with Spel/Smal and inserted into Spe/Smal p417-CYC or p427TEF vectors to produce the recombinant plasmids.

Competent Escherichia coli Top10F' strain cells were transformed with the recombinant plasmids, for expression of Enalp or aequorin. The presence of the appropriate insert was determined by DNA extraction, followed by digestion and sequencing with the chain termination method (MegaBace 1000 Sequencing Analysis System and DynamicTM ET dye terminator kit). Nucleic acid sequences were compared to sequences in the Saccharomyces Genome Database.

For $\mathrm{H}^{+}$-ATPase activity and bioluminescence assays, yeast cells were transformed by the lithium method [37].

2.8. Reproducibility of Results. All experiments were performed in triplicate. Means \pm SD are indicated in each figure, except for $\mathrm{H}^{+}$neutralisation and calcium signal experiments.

\section{Results}

3.1. $\mathrm{H}^{+}$Neutralisation Capacity. Previous results of our laboratory showed that $S$. boulardii (a probiotic strain) is more resistant to low $\mathrm{pH}$ than S. cerevisiae W303 (laboratory nonprobiotic strain). Therefore, we decided to test the behavior of these strains facing an acid pulse $(\mathrm{pH} 2.0$ plus $86 \mathrm{mM}$ $\mathrm{NaCl}$ or a simulated gastric environment without pepsin). As described before, low $\mathrm{NaCl}$ concentration seems to protect yeast cells against inorganic acid stress preventing exacerbated cell death due to extreme conditions. Figure 1 shows the extracellular and total (extracellular plus intracellular) $\mathrm{H}^{+}$neutralisation capacity of S. boulardii and S. cerevisiae W303 cells grown in YPD (control) and cells previously exposed to acid stress. The extracellular capacities of S. cerevisiae W303 


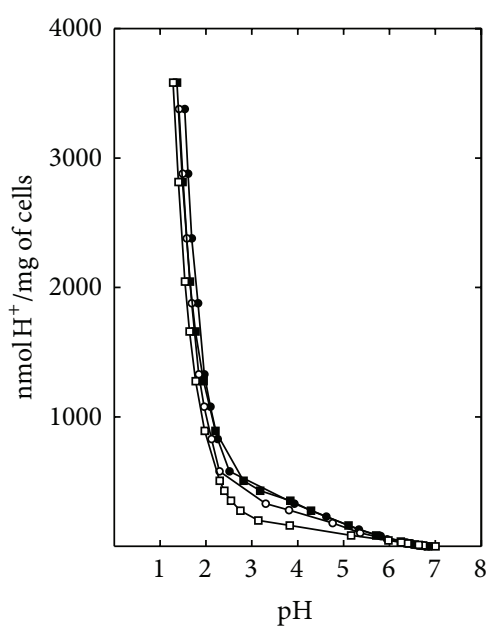

(a)

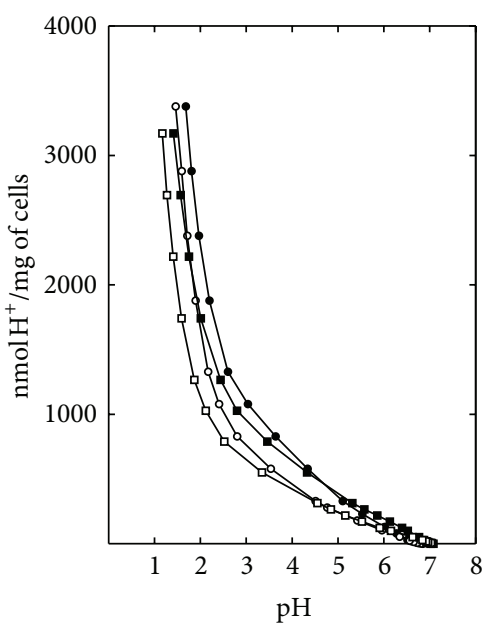

(b)

FIGURE 1: $\mathrm{H}^{+}$neutralisation capacity of yeast cells grown in YPD medium, as determined by an acid pulse technique. (a) Extracellular $\mathrm{H}^{+}$ neutralisation capacity of $S$. boulardii ( ), S. boulardii exposed to pH $2.0+86 \mathrm{mM} \mathrm{NaCl}$ (o), S. cerevisiae W303 (घ), and S. cerevisiae W303 exposed to $\mathrm{pH} 2.0+86 \mathrm{mM} \mathrm{NaCl}(\square)$. (b) Total $\mathrm{H}^{+}$neutralisation capacity of $S$. boulardii (๑), S. boulardii exposed to $\mathrm{pH} 2.0+86 \mathrm{mM} \mathrm{NaCl}$ (o), S. cerevisiae W303 (घ), and S. cerevisiae W303 exposed to pH $2.0+86 \mathrm{mM} \mathrm{NaCl}(\square)$.

and $S$. boulardii to neutralise added $\mathrm{H}^{+}$were similar, but S. cerevisiae W303 was lightly more affected by acid pulses than S. boulardii (Figure 1(a)). Results also demonstrated that the extracellular capacity to neutralise added $\mathrm{H}^{+}$was smaller than the total capacity for both yeast strains (Figures 1(a) and $1(b)$ ). This difference is particularly evident when we observe the resulting $\mathrm{pH}$ after the addition of a specific amount of $\mathrm{H}^{+} / \mathrm{mg}$ of cells. Saccharomyces boulardii had a higher total $\mathrm{H}^{+}$neutralisation capacity and possibly a greater ability to maintain $\mathrm{pH}$ homeostasis after acid stress than $S$. cerevisiae W303 (Figure 1(b)), suggesting that the two strains have different compositions of intracellular buffering compounds. The resulting $\mathrm{pH}$ after the addition of $1,000 \mathrm{nmol} \mathrm{H}^{+} / \mathrm{mg}$ of cells was 3.3 and 2.8 (in control cells or exposed to $\mathrm{pH}$ $2.0+86 \mathrm{mM} \mathrm{NaCl}$, resp.) for $S$. boulardii and $\mathrm{pH} 2.6$ and 2.2 for W303 (Figure 1(b)). This buffering mechanism is important for a rapid intracellular $\mathrm{pH}$ adjustment but cannot accommodate extreme changes in extracellular $\mathrm{pH}$. In fact, a $0.5 \mathrm{pH}$ unit difference in external medium, in low $\mathrm{pH}$ range, represents a pronounced stress condition.

3.2. Membrane Fatty Acid Composition. The composition and levels of fatty acids in the cell membrane were modulated in response to acid stress, as shown by a dendrogram shown in Figure 2. A passive increase in intracellular proton concentration may partially explain this cellular response to acid. This effect was particularly pronounced in the W303 strain, in which changes in fatty acid profile were observed after $30 \mathrm{~min}$ of acid exposure ( $\mathrm{pH}$ 2.0). Small increases were observed for oleic acid and arachidic acid, whereas the percentage of gadoleic acid, a cis-icos-9-enoic acid related to oleic acid but has 20 carbon atoms, presented a large decrease. Figure 2 also shows that the addition of $86 \mathrm{mM} \mathrm{NaCl}$ prevented this effect in the W303 strain and that membrane fatty acid composition of $S$. boulardii was unaffected by acidic $\mathrm{pH}$. It has been known that unsaturation of fatty acid chains has a profound effect on membrane fluidity, but further work will be needed to investigate if the changes in saturation and unsaturation degrees influence the acid tolerance.

3.3. $H^{+}$-ATPase Activity in Ena Mutants. To confirm the involvement of systems involved with maintaining the plasma membrane potential $\left(\mathrm{PMA} 1 / \mathrm{H}^{+}\right.$-ATPase and secondary transport systems) during the acid stress response, we constructed yeast strains expressing different levels of Enalp. While Pmalp is involved in protons active extrusion, ENA proteins act in the responses to saline or alkaline stress [38] and help to regulate the plasma membrane potential [29]. Saccharomyces cerevisiae contains several genes encoding ENA proteins but the ENA1 gene is the most functionally relevant component of the gene cluster [38]. Figure 3 shows the in vivo activation of the plasma membrane $\mathrm{H}^{+}$-ATPase by pulse acid $(\mathrm{pH} 2.0+86 \mathrm{mM} \mathrm{NaCl})$ in yeast strains with different levels of Enalp. The deletion strain (W303 ena1::HIS3::ena4), the W303 ena1::HIS3::ena4 strain transformed with the empty vectors, and the strain expressing single copy of ENA1 (W303 ena1::HIS3::ena4 + p417::ENA1) showed acid-induced $\mathrm{H}^{+}$ATPase activation. In contrast, no activation was observed in Saccharomyces strains expressing high levels of Enalp (W303 and W303 ena1::HIS3::ena4 + p427::ENA1). Table 2 shows that enals mutant presented higher tolerance to acid stress when viability of strains with different Enalp levels was compared to wild-type S. cerevisiae W303 (high ENA expression) over time. These results were confirmed by spot tests when tenfold serial dilutions of control and acid stressed cells were spotted onto YPD plates (results not shown). The more negative membrane potentials under standard growth conditions of ena null mutants and cells with low Enalp expression could explain the correlation between 


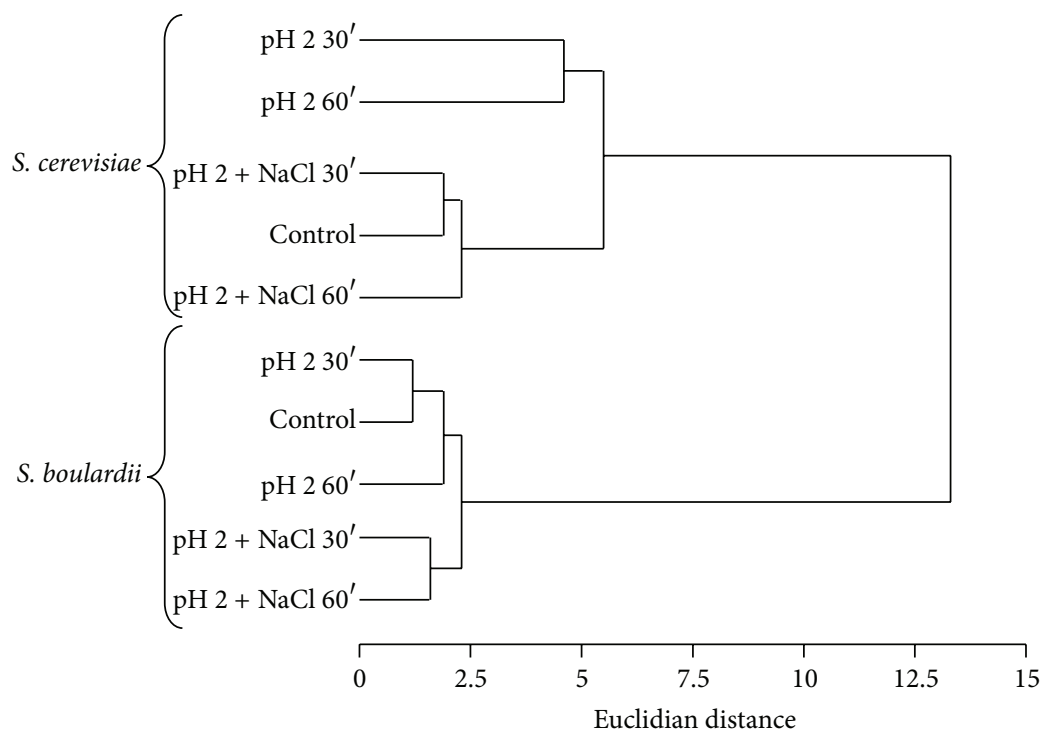

FIGURE 2: Dendrogram of the fatty acid composition of yeast cytoplasmic membranes. Data were analysed by the standardized Euclidian distance, and the calculated matrix distance was used for clustering analysis by the UPGMA method. The composition and levels of fatty acids in the cell membrane were modulated in response to acid stress, particularly in the W303 strain, and this effect was prevented by addition of $86 \mathrm{mM}$ of $\mathrm{NaCl}$ as shown by the dendrogram.

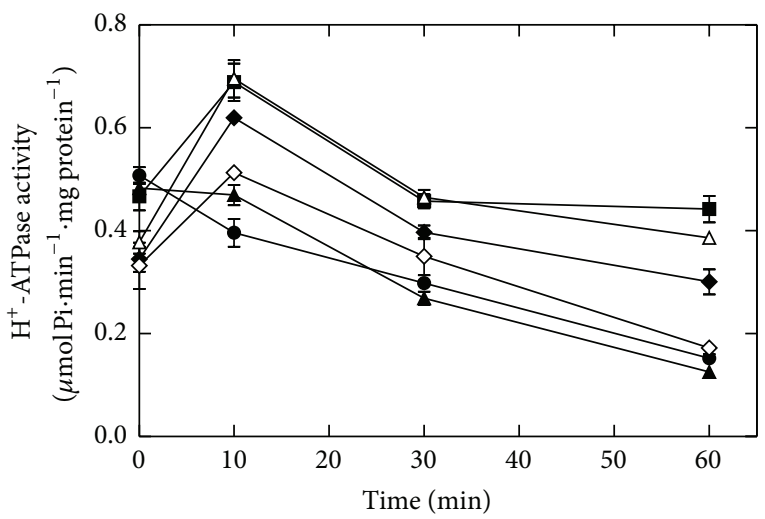

FIgURE 3: $\mathrm{H}^{+}$-ATPase activity. Plasma membrane $\mathrm{H}^{+}$-ATPase activation in wild S. cerevisiae W303 (-), the ena1-4 mutant $(\mathbf{\square})$, ena1-4 mutant + p417::ENA1 ( $)$, enal-4 mutant + p427::ENA1 (४), ena1-4 mutant $+\mathrm{p} 417(\diamond)$, and enal-4 mutant $+\mathrm{p} 427(\Delta)$ S. cerevisiae W303 mutants subjected to $\mathrm{pH} 2.0(\mathrm{HCl})+86 \mathrm{mM} \mathrm{NaCl}$ for $60 \mathrm{~min}$.

the ENA1 levels, the acid-induced plasma membrane $\mathrm{H}^{+}$ATPase activation, and the acid tolerance as demonstrated in a previous study [29]. In contrast, strains overexpressing Enalp have more positive membrane potentials and are not susceptible to acid-induced $\mathrm{H}^{+}$-ATPase activation. The strain expressing single copy (or maximum two copies of ENA1) showed lower viability compared to $S$. boulardii (low ENA1 expression and acid resistance, previous work [29]) possibly because W303 ena1::HIS3::ena4 + p417::ENA1 shows a different expression profile compared to $S$. boulardii (ectopic $\mathrm{x}$ eutopic expression). Subsequent experiments to understand the relationships between Enalp expression and acid induced $\mathrm{H}^{+}$-ATPase activation are necessary to confirm this hypothesis. In addition, other factors are involved in acid stress response.

3.4. Acid Induced Cytosolic $\mathrm{Ca}^{2+}$ Transient Increase. The calcium signal induced by glucose was well known and used as a positive control in the present experiment [39]. However, information on calcium transient signal in response to acid exposure is not available in the literature. As expected, yeast cells resuspended in Mes/Tris (0.1 M, pH 6.5) and submitted to glucose pulses showed clear glucose-induced calcium signal (Figure 4(a)). On the other hand, acid pulses produced very low cytosolic calcium signal which were $\mathrm{pH}$ dependent (Figure 4(b)). The effect of identical acid pulses was also measured in suspensions with lower cell density. We observed a higher calcium signal in these suspensions, likely because the denser cell suspensions had a higher buffering capacity (results not shown). However, the luminescence assay is $\mathrm{pH}$ sensitive, and other studies have demonstrated a relationship between $\mathrm{pH}$ and luminescence of coelenterazine [40]. To evaluate whether the transient acid-induced calcium signals were the result of $\mathrm{pH}$ changes, we performed a similar experiment using a $15 \mathrm{mM} \mathrm{KCl}$ pulse as a negative control. The $\mathrm{KCl}$ pulse did not induce $\mathrm{pH}$ change or stimulate luminescence (Figure 4(b)).

Figure 5 shows that calcineurin and CrZ1 were required to induce the acid stress response. This suggests that calcineurin, a protein phosphatase, is activated by exposure to acid and acts by modulating gene expression through dephosphorylation of the CrZlp/Tcnlp transcription factor and its translocation to the nucleus [25]. This pathway was blocked by addition of $1 \mu \mathrm{g} / \mathrm{mL}$ FK 506 (calcineurin inhibitor) to yeast cells culture at 0.5 O.D. The acid stress condition was only applied when the cell concentration reached 1.0 O.D. 
TABLE 2: Effect of acid stress on strain viability (\% cfu).

\begin{tabular}{|c|c|c|c|c|}
\hline \multirow{3}{*}{ Strains } & \multicolumn{4}{|c|}{ Conditions } \\
\hline & \multirow{2}{*}{ Control (nonstressful) } & \multicolumn{3}{|c|}{$\mathrm{pH} 2.0+86 \mathrm{mM} \mathrm{NaCl}$} \\
\hline & & $10 \mathrm{~min}$ & $30 \mathrm{~min}$ & $60 \mathrm{~min}$ \\
\hline W303 & 100 & $82.2 \pm 3.1$ & $70.1 \pm 5.0$ & $32.9 \pm 4.1$ \\
\hline LBCM479 (ena1-4A) & 100 & $96.6 \pm 4.2^{*}$ & $84.4 \pm 4.3^{*}$ & $67.3 \pm 3.1^{*}$ \\
\hline LBCM479 [p417:: ENA1] & 100 & $92.6 \pm 2.6^{*}$ & $77.7 \pm 0.6$ & $37.0 \pm 1.4$ \\
\hline LBCM479 [p427:: ENA1] & 100 & $88.0 \pm 1.6$ & $73.2 \pm 0.9$ & $38.9 \pm 3.5$ \\
\hline
\end{tabular}

Yeast cells were harvested during the exponential growth phase and subjected to $1 \mathrm{~h}$ of acidic stress (pH $2.0+86 \mathrm{mM} \mathrm{NaCl})$. Data are expressed as the mean \pm standard deviations of three separate experiments. ${ }^{*}(P$ values $<0.05$ compared to W303 strain).

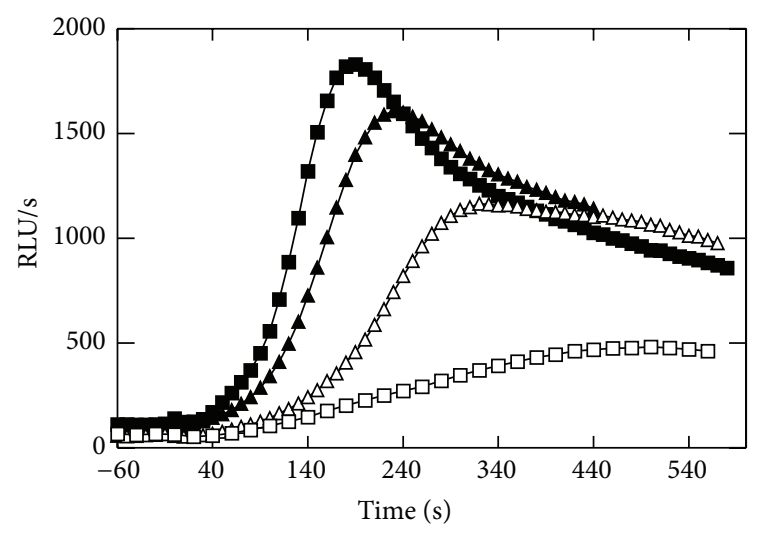

(a)

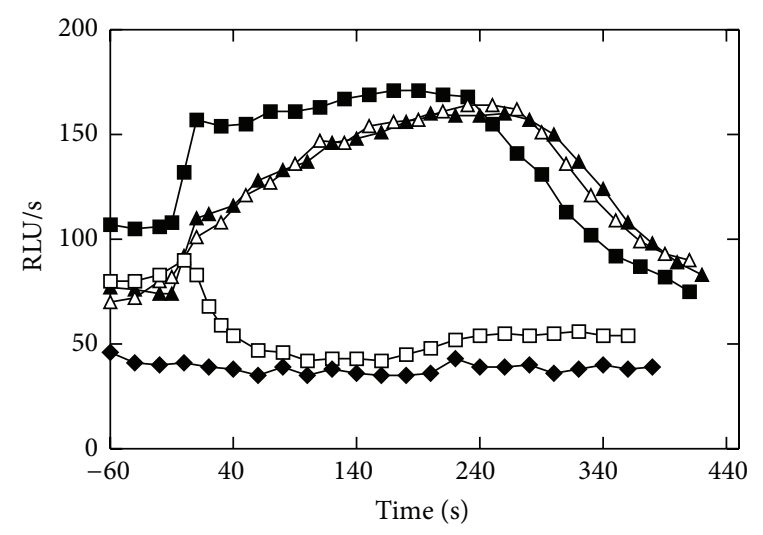

(b)

Figure 4: Calcium signalling in S. cerevisiae BY4741. (a) Glucose-induced calcium signalling at pH $6.5(\mathbf{\square}), \mathrm{pH} 3.7(\mathbf{\Delta}), \mathrm{pH} 3.0(\Delta)$, and pH 2.0 (口); (b) acid-induced calcium signalling at pH $5.1(\mathbf{\square}), \mathrm{pH} 4.2(\boldsymbol{\Delta}), \mathrm{pH} 3.0(\Delta), \mathrm{pH} 2.0(\square)$, and $15 \mathrm{mM} \mathrm{KCl}(\boldsymbol{})$.

These cells (incubated with FK506) were less resistant when compared to control cells (Figure 5). It is known that $S$. cerevisiae generates cytosolic calcium signals in response to diverse stimuli. These calcium transient signals mediate various responses in eukaryotic cells. For example, alkaline stress triggers calcium fluctuation in S. cerevisiae [5] and $C$. albicans [14]. Claret et al. [22] proposed the involvement of the cell calcium channel components Cchl and Mid1 in cell viability at low $\mathrm{pH}$.

\section{Discussion}

Changes in extracellular $\mathrm{pH}$ have a negative effect on the yeast life cycle and the maintenance of internal $\mathrm{pH}$ homeostasis is important for cell viability. Yeast cells can maintain an appropriate internal $\mathrm{pH}$ by utilizing cell buffer systems and consuming $\mathrm{H}^{+}$through metabolic pathways [41], increasing proton extrusion by the plasma membrane $\mathrm{H}^{+}$-ATPase [42, 43], transporting acid between the cytosol and organelles $[44,45]$. Our results confirm that the cell buffer power might be part of the $\mathrm{pH}$ homeostatic mechanism involved in the acid stress response. The composition and levels of fatty acids in the cell membrane were also modulated in response to acid stress. Here, we propose that modulation of composition and level of membrane fatty acids interferes with $\mathrm{H}^{+}$conductivity into the cells. Genes involved in the biosynthesis of plasma membrane lipids, which are essential

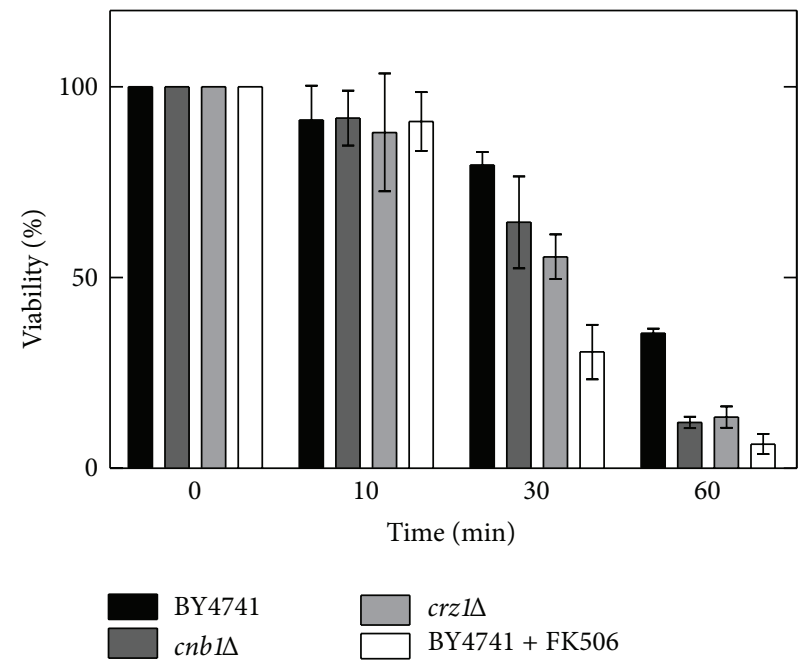

FIGURE 5: Effect of pH $2.0(\mathrm{HCl})+86 \mathrm{mM} \mathrm{NaCl}$ on calcineurin/crzl mutants. The results show that the acid stress response is dependent on calcium metabolism and is blocked by FK 506.

structural membrane components, have their expression modulated under stress [46, 47]. Plasma membrane structure is likely to affect yeast tolerance to low $\mathrm{pH}$ and other stresses [47]. We also showed an effect of sodium on the modulation of the fatty acid composition after acid stress (Figure 2). Our finding is in agreement with observations by Dos Santos 
Sant'Ana et al. [29], who reported that the addition of sodium conferred protection to yeast cells against acid stress. In fact, addition of sodium slowed depolarization promoted by proton influx. The authors suggested that, alternatively, the sodium effect could be related to unknown signalling events in response to acid stress. For instance, Bollo et al. [48] reported an effect of $120 \mathrm{mM}$ extracellular $\mathrm{NaCl}$ on $\mathrm{Ca}^{2+}$ mobilization from intracellular stores in Trypanosoma cruzi. The present work showed that sodium, through an indirect effect, is able to affect the modulation of membrane fatty acids in acid stress condition.

It is well known that cells of most organisms maintain high concentration ratios of extracellular to intracellular $\mathrm{H}^{+}$ across the plasma membrane and that stress factors leading to dissipation of the $\mathrm{H}^{+}$gradient across the plasma membrane and to intracellular acidification induce the stimulation of plasma membrane $\mathrm{H}^{+}$-ATPase activity. In this work we compared the activity of plasma membrane $\mathrm{H}^{+}$-ATPase in different yeast strains exposed to low $\mathrm{pH}$. The results indicate a $\mathrm{H}^{+}$-ATPase activation following the acid exposure. However, the level of activation, as previously suggested, and the great tolerance to acid were dependent on expression of secondary transport systems involved in maintaining the plasma membrane potential. This relationship between acid $\mathrm{H}^{+}$-ATPase activation and secondary systems needs to be clarified by studies of internal $\mathrm{pH}$, of membrane potential, and $\mathrm{H}^{+}$-ATPase activity in strains expressing different levels of a gene family, especially those encoding the most important ionic transporters.

In the yeast $S$. cerevisiae, calcineurin, a heterodimeric enzyme consisting of a catalytic (a) subunit and an associated calcium binding regulatory (b) subunit, is activated under specific environmental conditions and plays an important role in coupling $\mathrm{Ca}^{2+}$ signals to cellular responses. The sensitivity and response of the cells to various stresses are dependent on its ability to sequester and use $\mathrm{Ca}^{2+}$ from external and internal stores. Our results show that calcium signalling participates in acid stress response and that the stress response is calcineurin dependent. Crzl, a substrate phosphoprotein for calcineurin, functions downstream of calcineurin to effect calcineurin-dependent responses. Viability test results show similar phenotypes for $c n b 1 \Delta$ and $\operatorname{crz} 1 \Delta$ mutants.

The response of the yeast $S$. cerevisiae to environmental stress results in remodelling of gene expression. In previous studies, the genome response to acid stress has been evaluated by DNA microarray analysis and a functional screening performed using a gene deletion collection $[9,17]$. The expression analysis showed that genes involved in stress responses, such as YGP1, TPS1, and HSP150, were upregulated after acid shock and that genes involved in metal metabolism or regulated by Aftlp were induced under the acid adaptation [17]. The last study also indicated that loss of V-ATPase and Hog-MAPK proteins caused acid sensitivity. Mildly stressing acidic conditions (e.g., shift from $\mathrm{pH} 6$ to $\mathrm{pH} 3$ ) do not affect S. cerevisiae growth but instead may be slightly beneficial [8]. However, proteins in the cell wall have been shown to be upregulated in response to low $\mathrm{pH}[8,17,49]$.
Some studies on the effect of acidic $\mathrm{pH}$ on yeast show that PKC cell wall integrity pathway is activated in response to low $\mathrm{pH}$ and that RGDlp (Hog pathway) plays a role in response to acidic $\mathrm{pH}$ [22-24]. In more recent work, using screening deletion mutants and gene expression profile, de Lucena et al. [50] showed that the cell wall integrity pathway is the main mechanism for cell tolerance to sulphuric acid $\mathrm{pH}$ 2.5 and that $\mathrm{Ca}^{2+}$-calmodulin pathway is also responsive to this type of stress. Here, we have shown that cytosolic free calcium levels increase under acid shock and that calcineurin is an important transducer of calcium signals in acid stress responses.

In conclusion, the results of the present study show that the $\mathrm{H}^{+}$internal concentration of yeast is regulated by several systems, including the plasma membrane $\mathrm{H}^{+}$-ATPase, and that Enalp has an important but undefined role in the cellular response to acid. We also demonstrated that the acid stress response is dependent on calcium metabolism and blocked by FK 506. RNA-seq and microarray studies using different S. cereviseae strains, including S. boulardii, are currently being performed to provide some insight into the mechanisms of acid stress response. In parallel, experiments aiming to characterize the calcium signal (external or internal) and the dependence of the acid response pathway on calcineurin/Crzlp are under way.

\section{Conflict of Interests}

The authors declare that there is no conflict of interests regarding the publication of this paper.

\section{Acknowledgments}

This work was supported by Grants from Fundação de Amparo à Pesquisa do Estado de Minas Gerais (FAPEMIG) (CBB APQ 00333-10/CBB APQ 00482/11) and from Conselho Nacional de Desenvolvimento Científico e Tecnológico (CNPq) to Ieso Miranda Castro (Process 304259/2011-0). Júlio César Câmara Rosa and Ana Paula do Carmo were supported by fellowships from Coordenação de Aperfeiçoamento de Pessoal do Ensino Superior (CAPES). English language in the paper was revised by Write Science Right (http://www.writescienceright.com/).

\section{References}

[1] L. Trabalzini, A. Paffetti, A. Scaloni et al., "Proteomic response to physiological fermentation stresses in a wild-type wine strain of Saccharomyces cerevisiae," Biochemical Journal, vol. 370, no. 1, pp. 35-46, 2003.

[2] M. Platara, A. Ruiz, R. Serrano, A. Palomino, F. Moreno, and J. Ariño, "The transcriptional response of the yeast $\mathrm{Na}^{+}$-ATPase ENAl gene to alkaline stress involves three main signaling pathways," The Journal of Biological Chemistry, vol. 281, no. 48, pp. 36632-36642, 2006.

[3] Y. Araki, H. Wu, H. Kitagaki, T. Akao, H. Takagi, and H. Shimoi, "Ethanol stress stimulates the $\mathrm{Ca}^{2+}$-mediated calcineurin/Crzl pathway in Saccharomyces cerevisiae," Journal of Bioscience and Bioengineering, vol. 107, no. 1, pp. 1-6, 2009. 
[4] A. Daquinag, M. Fadri, S. Y. Jung, J. Qin, and J. Kunz, “The yeast $\mathrm{PH}$ domain proteins Slm1 and Slm2 are targets of sphingolipid signaling during the response to heat stress," Molecular and Cellular Biology, vol. 27, no. 2, pp. 633-650, 2007.

[5] J. Ariño, "Integrative responses to high $\mathrm{pH}$ stress in S. cerevisiae," OMICS A Journal of Integrative Biology, vol. 14, no. 5, pp. 517-523, 2010.

[6] A. P. Gasch, P. T. Spellman, C. M. Kao et al., "Genomic expression programs in the response of yeast cells to environmental changes," Molecular Biology of the Cell, vol. 11, no. 12, pp. 42414257, 2000.

[7] H. F. De Melo, B. M. Bonini, J. Thevelein, D. A. Simões, and M. A. Morais Jr., "Physiological and molecular analysis of the stress response of Saccharomyces cerevisiae imposed by strong inorganic acid with implication to industrial fermentations," Journal of Applied Microbiology, vol. 109, no. 1, pp. 116-127, 2010.

[8] A. K.-L. Chen, C. Gelling, P. L. Rogers, I. W. Dawes, and B. Rosche, "Response of Saccharomyces cerevisiae to stress-free acidification," Journal of Microbiology, vol. 47, no. 1, pp. 1-8, 2009.

[9] H. C. Causton, B. Ren, S. S. K. Sang Seok Koh et al., "Remodeling of yeast genome expression in response to environmental changes," Molecular Biology of the Cell, vol. 12, no. 2, pp. 323337, 2001.

[10] R. Serrano, A. Ruiz, D. Bernal, J. R. Chambers, and J. Ariño, "The transcriptional response to alkaline $\mathrm{pH}$ in Saccharomyces cerevisiae: evidence for calcium-mediated signalling," Molecular Microbiology, vol. 46, no. 5, pp. 1319-1333, 2002.

[11] R. Serrano, H. Martín, A. Casamayor, and J. Ariño, "Signaling alkaline $\mathrm{pH}$ stress in the yeast Saccharomyces cerevisiae through the Wscl cell surface sensor and the Slt2 MAPK pathway," The Journal of Biological Chemistry, vol. 281, no. 52, pp. 3978539795, 2006.

[12] L. Viladevall, R. Serrano, A. Ruiz et al., "Characterization of the calcium-mediated response to alkaline stress in Saccharomyces cerevisiae," The Journal of Biological Chemistry, vol. 279, no. 42, pp. 43614-43624, 2004.

[13] M. Karababa, E. Valentino, G. Pardini, A. T. Coste, J. Bille, and D. Sanglard, "CRZ1, a target of the calcineurin pathway in Candida albicans," Molecular Microbiology, vol. 59, no. 5, pp. 1429-1451, 2006.

[14] H. Wang, Y. Liang, B. Zhang, W. Zheng, L. Xing, and M. Li, "Alkaline stress triggers an immediate calcium fluctuation in Candida albicans mediated by Rim101p and Crzlp transcription factors," FEMS Yeast Research, vol. 11, no. 5, pp. 430-439, 2011.

[15] S. H. Denison, "pH regulation of gene expression in fungi," Fungal Genetics and Biology, vol. 29, no. 2, pp. 61-71, 2000.

[16] M. A. Peñalva, J. Tilburn, E. Bignell, and H. N. Arst Jr., "Ambient $\mathrm{pH}$ gene regulation in fungi: making connections," Trends in Microbiology, vol. 16, no. 6, pp. 291-300, 2008.

[17] M. Kawahata, K. Masaki, T. Fujii, and H. Iefuji, "Yeast genes involved in response to lactic acid and acetic acid: acidic conditions caused by the organic acids in Saccharomyces cerevisiae cultures induce expression of intracellular metal metabolism genes regulated by Aftlp," FEMS Yeast Research, vol. 6, no. 6, pp. 924-936, 2006.

[18] P. Piper, C. O. Calderon, K. Hatzixanthis, and M. Mollapour, "Weak acid adaptation: the stress response that confers yeasts with resistance to organic acid food preservatives," Microbiology, vol. 147, no. 10, pp. 2635-2642, 2001.
[19] M. G. Cabral, I. Sá-Correia, and C. A. Viegas, "Adaptative responses in yeast to the herbicide 2-methyl-4- chlorophenoxyacetic acid at the level of intracellular $\mathrm{pH}$ homeostasis," Journal of Applied Microbiology, vol. 96, no. 3, pp. 603-612, 2004.

[20] M. Mollapour and P. W. Piper, "Targeted gene deletion in Zygosaccharomyces bailii," Yeast, vol. 18, no. 10, pp. 173-186, 2001.

[21] P. Eraso and C. Gancedo, "Activation of yeast plasma membrane ATPase by acid pH during growth," FEBS Letters, vol. 224, no. 1, pp. 187-192, 1987.

[22] S. Claret, X. Gatti, F. Doignon, D. Thoraval, and M. Crouzet, "The Rgd1p Rho GTPase-activating protein and the Mid2p cell wall sensor are required at low $\mathrm{pH}$ for protein kinase $\mathrm{C}$ pathway activation and cell survival in Saccharomyces cerevisiae," Eukaryotic Cell, vol. 4, no. 8, pp. 1375-1386, 2005.

[23] X. Gatti, G. De Bettignies, S. Claret, F. Doignon, M. Crouzet, and D. Thoraval, "RGD1, encoding a RhoGAP involved in low-pH survival, is an Msn2p/Msn4p regulated gene in Saccharomyces cerevisiae," Gene, vol. 351, pp. 159-169, 2005.

[24] H. Fernandes, O. Roumanie, S. Claret et al., "The Rho3 and Rho4 small GTPases interact functionally with Wsclp, a cell surface sensor of the protein kinase C cell-integrity pathway in Saccharomyces cerevisiae," Microbiology, vol. 152, no. 3, pp. 695708, 2006.

[25] K. W. Cunningham, "Acidic calcium stores of Saccharomyces cerevisiae," Cell Calcium, vol. 50, no. 2, pp. 129-138, 2011.

[26] T. K. Matsumoto, A. J. Ellsmore, S. G. Cessna et al., "An osmotically induced cytosolic $\mathrm{Ca}^{2+}$ transient activates calcineurin signaling to mediate ion homeostasis and salt tolerance of Saccharomyces cerevisiae," The Journal of Biological Chemistry, vol. 277, no. 36, pp. 33075-33080, 2002.

[27] M. Bonilla and K. W. Cunningham, "Mitogen-activated protein kinase stimulation of $\mathrm{Ca}^{2+}$ signaling is required for survival of endoplasmic reticulum stress in yeast," Molecular Biology of the Cell, vol. 14, no. 10, pp. 4296-4305, 2003.

[28] C.-V. Popa, I. Dumitru, L. L. Ruta, A. F. Danet, and I. C. Farcasanu, "Exogenous oxidative stress induces $\mathrm{Ca}^{2+}$ release in the yeast Saccharomyces cerevisiae," FEBS Journal, vol. 277, no. 19, pp. 4027-4038, 2010.

[29] G. Dos Santos Sant'Ana, L. Da Silva Paes, A. F. Vieira Paiva et al., "Protective effect of ions against cell death induced by acid stress in Saccharomyces," FEMS Yeast Research, vol. 9, no. 5, pp. 701-712, 2009.

[30] T. A. Krulwich, R. Agus, M. Schneier, and A. A. Guffanti, "Buffering capacity of bacilli that grow at different $\mathrm{pH}$ ranges," Journal of Bacteriology, vol. 162, no. 2, pp. 768-772, 1985.

[31] J. Becher Dos Passos, M. Vanhalewyn, R. Lopes Brandao, I. M. Castro, J. R. Nicoli, and J. M. Thevelein, "Glucose-induced activation of plasma membrane $\mathrm{H}^{+}$-ATPase in mutants of the yeast Saccharomyces cerevisiae affected in cAMP metabolism, cAMP-dependent protein phosphorylation and the initiation of glycolysis," Biochimica et Biophysica Acta: Molecular Cell Research, vol. 1136, no. 1, pp. 57-67, 1992.

[32] O. H. Lowry, N. J. Rosebrough, A. L. Farr, and R. J. Randall, "Protein measurement with the Folin phenol reagent," The Journal of Biological Chemistry, vol. 193, no. 1, pp. 265-275, 1951.

[33] R. Tisi, S. Baldassa, F. Belotti, and E. Martegani, "Phospholipase $\mathrm{C}$ is required for glucose-induced calcium influx in budding yeast," FEBS Letters, vol. 520, no. 1-3, pp. 133-138, 2002.

[34] M. C. Pereira, N. M. Vieira, M. R. Tótola, and M. C. M. Kasuya, "Total fatty acid composition in the characterization and identification of orchid mycorrhizal fungi Epulorhiza spp," 
Revista Brasileira de Ciencia do Solo, vol. 35, no. 4, pp. 1159-1165, 2011.

[35] C. D. Cruz, Programa genes: diversidade genética [Ph.D. thesis], Universidade Federal de Viçosa, Viçosa, MG, Brazil, 2008.

[36] J. Sambrook, E. F. Fritsch, and T. Maniatis, Molecular Cloning: A Laboratory Manual, Cold Spring Harbor Laboratory Press, Cold Spring Harbor, NY, USA, 2nd edition, 1989.

[37] H. Ito, Y. Fukuda, K. Murata, and A. Kimura, "Transformation of intact yeast cells treated with alkali cations," Journal of Bacteriology, vol. 153, no. 1, pp. 163-168, 1983.

[38] A. Ruiz and J. Ariño, "Function and regulation of the Saccharomyces cerevisiae ENA sodium ATPase system," Eukaryotic Cell, vol. 6, no. 12, pp. 2175-2183, 2007.

[39] M. J. M. Trópia, A. S. Cardoso, R. Tisi et al., "Calcium signaling and sugar-induced activation of plasma membrane $\mathrm{H}^{+}$-ATPase in Saccharomyces cerevisiae cells," Biochemical and Biophysical Research Communications, vol. 343, no. 4, pp. 1234-1243, 2006.

[40] Y. Zang, Q. Xie, J. B. Robertson, and C. H. Johnson, "pHlash: a new genetically encoded and ratiometric luminescence sensor of intracellular pH," PLoS ONE, vol. 7, Article ID 43072, 2012.

[41] M. J. Carlisle, S. C. Watkinson, and G. W. Gooday, The Fungi, Academic Press, San Diego, Calif, USA, 2nd edition, 2001.

[42] R. Serrano, M. C. Kielland-Brandt, and G. R. Fink, "Yeast plasma membrane ATPase is essential for growth and has homology with $\left(\mathrm{Na}^{+}, \mathrm{K}^{+}\right), \mathrm{K}^{+}$and $\mathrm{Ca}^{2+}$-ATPases," Nature, vol. 319, no. 6055, pp. 689-693, 1986.

[43] F. Portillo, "Regulation of plasma membrane $\mathrm{H}^{+}$-ATPase in fungi and plants," Biochimica et Biophysica Acta: Reviews on Biomembranes, vol. 1469, no. 1, pp. 31-42, 2000.

[44] V. Carmelo, H. Santos, and I. Sá-Correia, "Effect of extracellular acidification on the activity of plasma membrane ATPase and on the cytosolic and vacuolar $\mathrm{pH}$ of Saccharomyces cerevisiae," Biochimica et Biophysica Acta: Biomembranes, vol. 1325, no. 1, pp. 63-70, 1997.

[45] G. A. Martínez-Muñoz and P. Kane, "Vacuolar and plasma membrane proton pumps collaborate to achieve cytosolic $\mathrm{pH}$ homeostasis in yeast," The Journal of Biological Chemistry, vol. 283, no. 29, pp. 20309-20319, 2008.

[46] J. Ding, X. Huang, L. Zhang, N. Zhao, D. Yang, and K. Zhang, "Tolerance and stress response to ethanol in the yeast Saccharomyces cerevisiae," Applied Microbiology and Biotechnology, vol. 85, no. 2, pp. 253-263, 2009.

[47] N. P. Mira, M. Palma, J. F. Guerreiro, and I. Sá-Correia, "Genome-wide identification of Saccharomyces cerevisiae genes required for tolerance to acetic acid," Microbial Cell Factories, vol. 9, article 79, 2010.

[48] M. Bollo, S. Bonansea, and E. E. Machado, "Involvement of $\mathrm{Na}^{+} / \mathrm{H}^{+}$exchanger in the calcium signaling in epimastigotes of Trypanosoma cruzi," FEBS Letters, vol. 580, no. 11, pp. 26862690, 2006.

[49] J. C. Kapteyn, B. Ter Riet, E. Vink et al., "Low external ph induces HOG1-dependent changes in the organization of the Saccharomyces cerevisiae cell wall," Molecular Microbiology, vol. 39, no. 2, pp. 469-479, 2001.

[50] R. M. de Lucena, C. Elsztein, D. A. Simões, and M. A. Morais Jr, "Participation of CW1, HOG and calcineurin pathways in the tolerance of Saccharomyces to low $\mathrm{pH}$ by inorganic acid," Journal of Applied Microbiology, vol. 113, no. 3, pp. 629-640, 2012. 

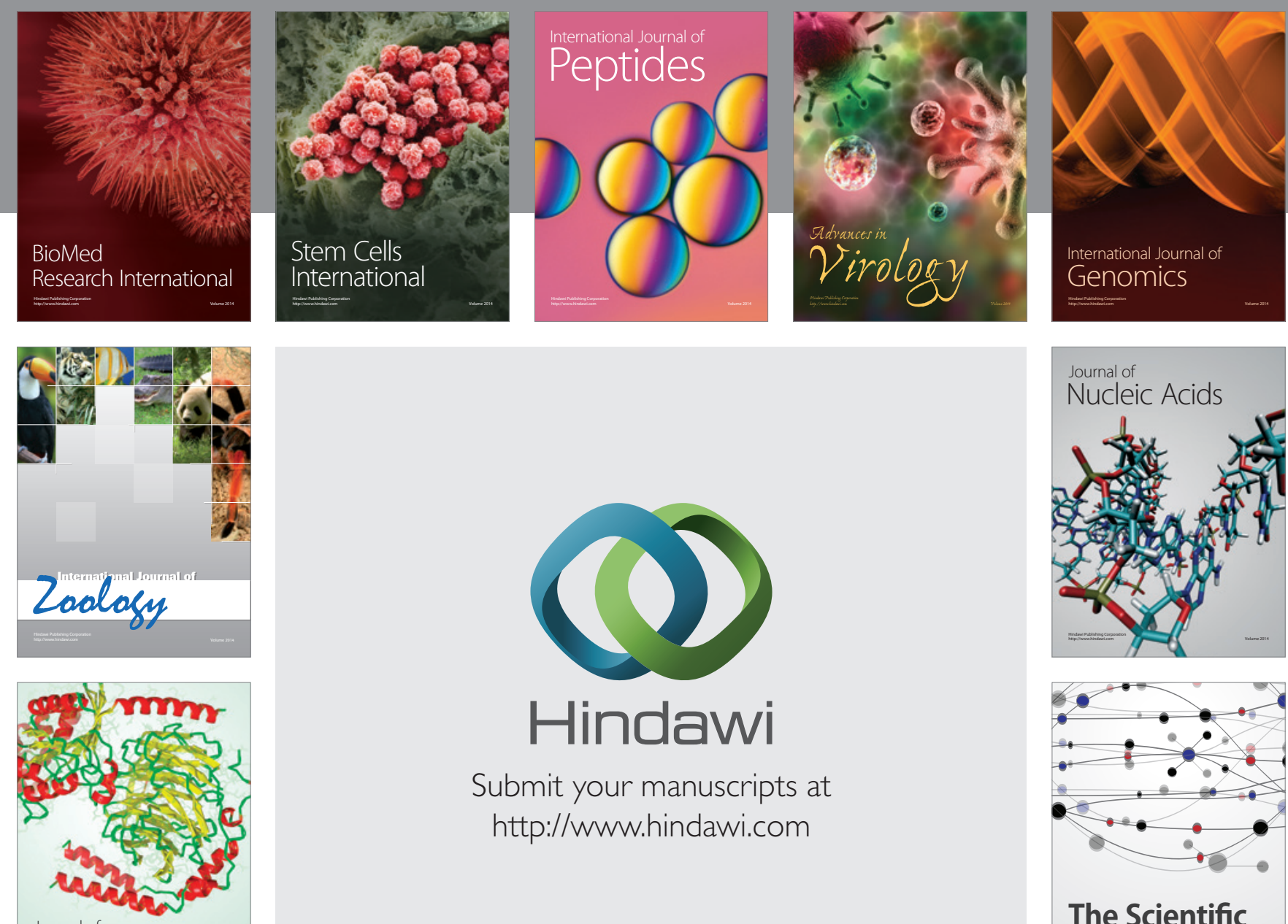

Submit your manuscripts at

http://www.hindawi.com

Journal of
Signal Transduction
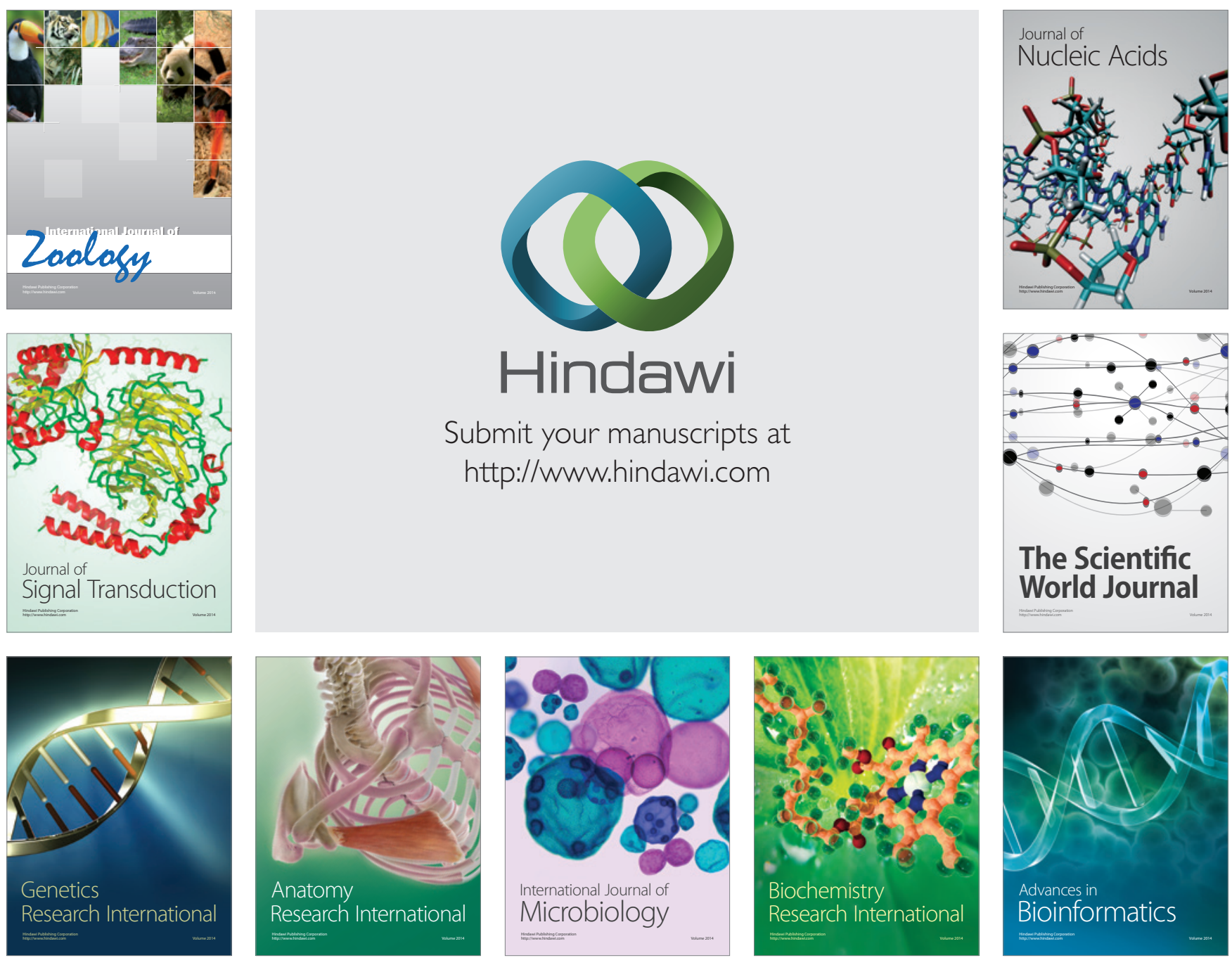

The Scientific World Journal
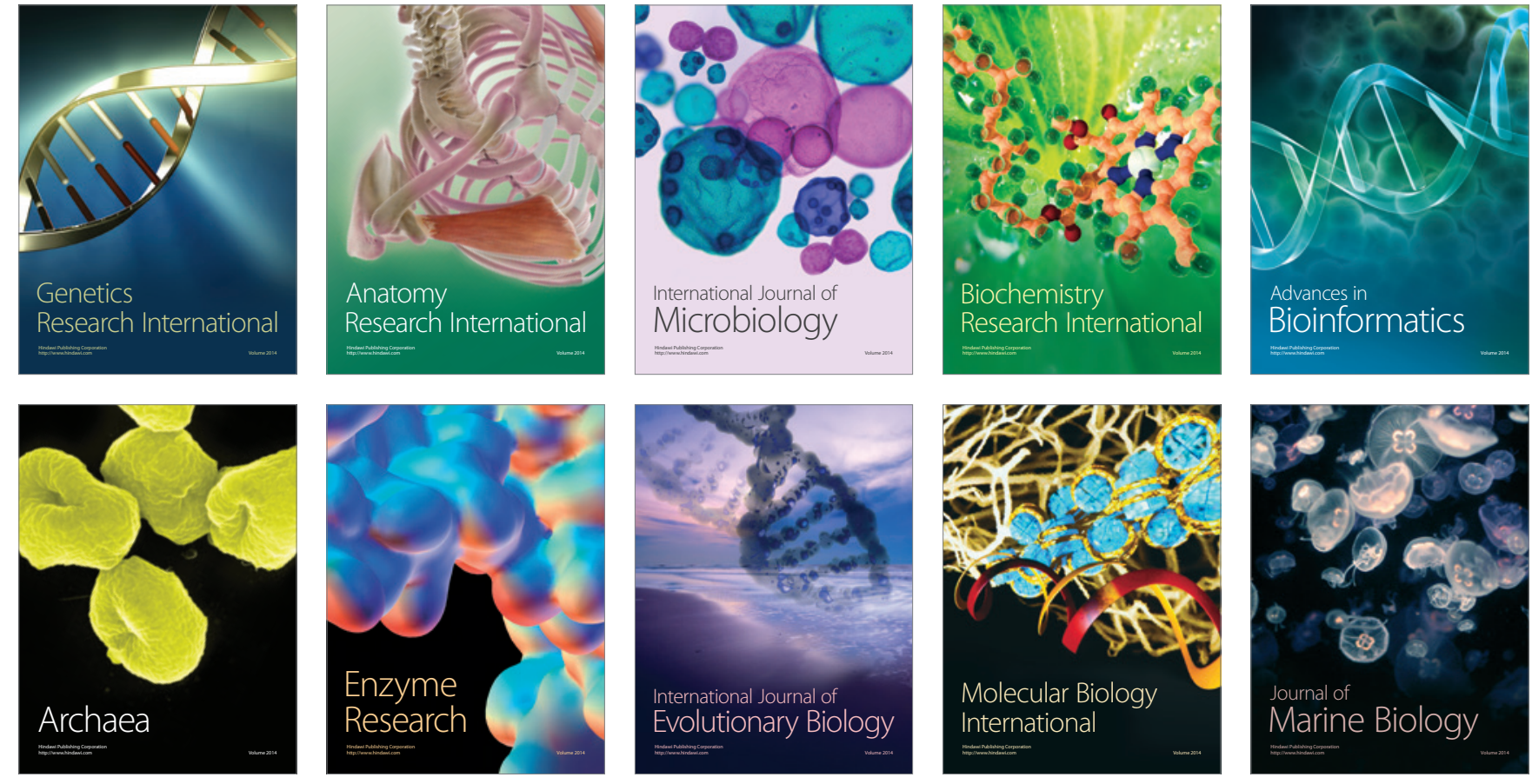